NBSIR 76-1172

\title{
A New Test Method for Automatic Fire Detection Devices
}

Richard G. Bright

Center for Fire Research

Institute for Applied Technology

National Bureau of Standards

Washington, D. C. 20234

\section{December 1976}

Final Report

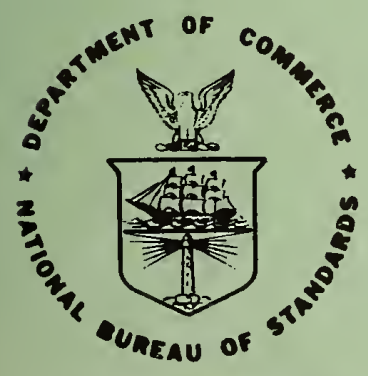

U. S. DEPARTMENT OF COMMERCE NATIONAL BUREAU OF STANDARDS 



\section{A NEW TEST METHOD FOR AUTOMATIC FIRE DETECTION DEVICES}

Richard G. Bright

Center for Fire Research

Institute for Applied Technology

National Bureau of Standards

Washisngton, D. C. 20234

December 1976

Final Report

U.S. DEPARTMENT OF COMMERCE, Elliot L. Richardson, Secretary Edward O. Vetter, Under Secretary

Dr. Betsy Ancker-Johneon. Assistant Secretary for Science and Technology NATIONAL BUREAU OF STANDARDS, Ernest Ambler, Acting Diroctor 
PREFACE

This report is an adaptation of a paper presented by the author at the 80th Annual Meeting of the National Fire Protection Association, on May 18, 1976, in Houston, Texas. 

CONTENTS

Page

PREFACE . . . . . . . . . . . . . . . . . . iii

LIST OF FIGURES . . . . . . . . . . . . . . . . vi

LIST OF TABLES. . . . . . . . . . . . . . . . . vi

Abstract . . . . . . . . . . . . . . . . 1

BODY OF PAPER . . . . . . . . . . . . . . . 2

REFERENCES. . . . . . . . . . . . . . . . 13 


\section{LIST OF FIGURES}

Page

Figure 1. Geometry of Detector Test Laboratory . . .

Figure 2. Position of the Detectors and Measuring Devices on Ceiling of Detector Test Laboratory

\section{LIST OF TABLES}

Page

Table 1. Types of Automatic Fire Detection Devices.

Table 2. Proposed Standard Test Fires . . . . . . 16

Table 3. Test Fire No. 1 - Flaming Cellulosic . . . 17

Table 4. Test Fire No. 2 - Smoldering Cellulosic. . 17

Table 5. Test Fire No. 3 - Flaming Plastic . . . 18

Table 6. Test Fire No. 4 - Flammable Liquid w/

Smoke.............. . 18

Table 7. Test Fire No. 5 - Flammable Liquid w/Heat. 19

Table 8. Fire Detector Classification Table Typical Results for: Ionization Smoke Detector . . . . . . . . . . . 20

Table 9. Fire Detector Classification - Typical Results for: Photoelectric Smoke Detector 21

Table 10. Fire Detector Classification - Typical Results for: Heat Detector. . . . . .

Table 11. Fire Detector Classification - Typical Results for: Infrared Flame Detector. . 
A NEW TEST METHOD FOR AUTOMATIC

FIRE DETECTION DEVICES

Richard G. Bright

\section{Abstract}

An analysis of the test methods for automatic fire detection devices in the U.S. reveals the fact that different types and different sizes of fires are used to evaluate different classes of detectors. The result is a lack of comparison test data for each detector class and, as a consequence, intelligent decisions can not be made in the selection of automatic fire detectors for specific fire risks. A new test method is proposed in which all automatic fire detectors, regardless of sensor type, would be subjected to a series of the same test fires. In addition, each test fire series would consist of three different test fire sizes. From the results obtained, it should then be possible to match a detector's characteristics against a specific fire risk resulting in a more intelligent application of automatic fire detectors.

Key words: Fire detector; test methods. 
Each hostile fire produces a multitude of physical and chemical characteristics. Some of these characteristics are unique to the fire. Other characteristics are already present in the environment and the fire only changes these background characteristics, usually by augmenting them. All of these fire-produced characteristics, or combinations thereof, can be used to identify the presence of the hostile fire. Some of these fire-produced characteristics give stronger signals earlier in the fire growth than others. As such, these signals are superior, as earlier, unambiguous fire indicators.

There are in excess of a dozen different types of automatic fire detection devices available to the fire safety engineer. Some of these detectors sense physical changes in the environment resulting from the fire. Other detectors sense chemical changes in the environment. Table No. 1 presents some, but not all, of the different types of detection devices.

All automatic fire detectors possess one common attribute. Each is expected to detect a hostile fire early enough to allow for effective counter measures, be it the evacuation of threatened persons and/or the extinguishment of the fire. But the different types of fire detectors do not detect all types of fires with the same degree of rapid- 
ity. This fact is fairly well known. What isn't well known, however, is the magnitude of difference in response of these different detectors to different fires. If, for example, one were to describe several hypothetical fires in a specific compartment and then ask at what point in the fire growth each of the different detector types could be expected to respond, it is quite likely that 9 out of 10 persons could not answer this question accurately.

Part of the reason for this is that the needed information is not readily available with which to answer questions such as these. Yet, some of us are called upon from timeto-time to select a fire detector for a specific fire risk. What do we do? Most likely, we listen to or read the claims of competing manufacturers and try to sort out the kernels from the husks. If the number of telephone calls our office receives is any indication, we are not too successful at this sorting process.

A portion of the problem lies in the way we test and approve automatic fire detection devices in the U.S. With our present system, a completely different series of test fires are used for each type of automatic fire detection device. In addition, there is no grading of the fire sizes, especially with regards to smoke detectors, so that the tests are essentially "go - no go" tests. The results, 
therefore, cannot be intelligently used to compare one detector against another and, consequently, intelligent utilization of the devices can not always be made. Wouldn't it be nice if we had a test method which included one each of all the representative types of fires a detector may encounter and that these fires were graded in size so that the discrimination level of each detector was readily apparent? More on this in a moment but first I would like to review the essentials in the testing of automatic fire detection devices.

The best test of an automatic fire detection device and it probably will always be so - is their use in practice over many years under the most diverse conditions. This is, of course, not always possible, particularly with more recent products. One clearly cannot wait, sometimes for several years, for the experience to accumulate as to the advantages and limitations of the fire detection device.

At the present time, laboratory tests of automatic fire detection devices are designed to provide yes/no decisions on the premise that unsuitable detectors are determined and eliminated by these laboratory tests. One then waits to see whether those detectors which have passed the tests subsequently prove themselves in the field. 
Undoubtedly, such laboratory tests coupled with field experience are better than no tests. In the long run, however, a different type of test for automatic fire detection devices appears to be necessary. The aim of such a test should be to determine and fully describe the behavior of the automatic fire detection device. Here too, noncompliance with certain minimum requirements would disqualify the device. But in addition to establishing compliance with the basic requirements, an attempt should also be made to establish the limits of the capabilities of the detector and the conditions under which it can attain these limits. In so doing, not only would the detector be passed as meeting the basic requirements, but the results would give some indication as to the suitability, or unsuitability, of the detector for specific fire risks.

The requirements and associated test methods can be divided into two groups. In the first group, the influence of adverse environmental effects, to which a detector may be subjected, are investigated. We'll call this first group the basic tests. In most cases the procedure is as follows.

The automatic fire detector to be tested is exposed to a simulated, ever-increasing fire characteristic. The alarm point of the detector i's determined. Then the detector is subjected to a series of environmental stresses such as high 
humidity, dust, high temperature, corrosion, vibration, etc. The alarm point is again measured, using the procedure described previously, to see whether and to what extent the alarm point has changed.

Obviously, good repeatability of the simulated fire characteristic and reliability of the measuring devices must be obtained. Only in this way can one be sure that any changes in the alarm point of the detector are due to changes in the test specimen and not in changes in the simulated fire characteristic or in changes in the measuring devices themselves. There are some problems with our basic test procedures, as presently conducted in the U.S., but they are probably of less concern than the problems encountered in the second group of tests.

This second group we'll call the trial test. In this group of tests, several of the automatic fire detectors under investigation are exposed to actual test fires, and their behavior recorded. In principle, all automatic fire detectors should be exposed to the same test fires. In this way, comparisons can be made of the response characteristics of the various fire detectors to differing fire types. As a matter of fact, they are not. And herein lies the substance of my talk. 
I want to introduce today a proposed new test method for the evaluation of automatic fire detectors to real test fires. This test method, while new to the U.S., has been in use for about five years in West Germany. It has been formulated and published as the test method for Germany [1] ${ }^{1}$. Also, this test method has been adopted by the European Insurance Association [2] as their standard for Europe. As a consequence, it seems safe to presume that many of the normal test anamolies have been eliminated from the test method.

The test method is composed of five types of fires. These fires, which are shown in table No. 2 , have been selected to represent a broad spectrum of fire types. In addition, the five test fires are divided into three sizes. These three sizes have been selected to encompass the range of sensitivities which can be expected from automatic fire detection devices. Each fire is about twice the size of the next smaller fire. Table Nos. 3 to 7 present a description of the fuels as well as the three sizes used in each of the five test fires.

The class I fire, the smallest in each type of fire, is representative of the smallest fire a detector can be expected

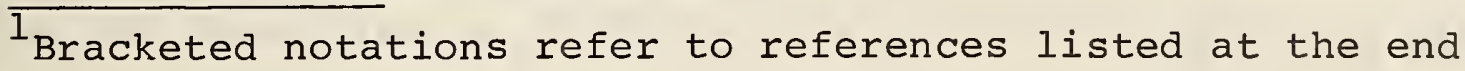
of this paper. 
to respond to and still remain reasonably free from false alarms, at least in most cases. The class III fire, the largest in each type of fire, is representative of the largest fire that can be tolerated and still have sufficient time to summon effective fire fighting assistance. Fires which grow at a rate exceeding the class III fire are probably not suitable for automatic fire detection. Other fire safety means, such as automatic suppression, are called for in situations such as these.

The geometry of the room in which these fire tests are conducted is, as one would expect, crucial to the results obtained in the tests. Figure 1 is an isometric view of one suggested test structure. The test fires are located in the center of the room. The detectors to be tested are placed on the ceiling, 3 meters (10 feet) from the center of the room. Measuring instruments, consisting of a smoke meter, a reference ionization chamber measuring device, and thermocouples, are also placed 3 meters (10 feet) from the center of the room. A ceiling plan of the detector and measuring instrument locations is shown in figure 2. The room should be at a temperature of $21 \pm 3{ }^{\circ} \mathrm{C}\left(70 \pm 5{ }^{\circ} \mathrm{F}\right)$ and free of smoke before each test. The specific dimensions chosen for the test structure are those used by West Germany for their test structure. 
For tests of smoke detectors, test fires Nos. 1 through 5 would be conducted. Most of the presently available detectors which respond to smoke aerosols will not respond to test fire No. 5, the clean-burning alcohol fire. As a consequence, test fire No. 5 could be deleted for tests of generic classes of smoke detectors not responsive to cleanburning alcohol. This would include, for example, ionization chamber smoke detectors and optical smoke detectors.

For heat detectors, test fires Nos. 1,3 and 5 would be conducted. Test fires Nos. 2 and 4 would not be conducted as these test fires produce only slight changes in the ambient temperatures at the detector location.

For other automatic fire detection devices, such as flame detectors, combustible gas detectors, and cloud chambers, for example, all five test fires would be conducted, at least, until it became apparent which test fires would be deleted from the test series due to lack of detector response to these fires.

The procedure would be to start with the first fire commencing in each case with the smallest fire or class I fire. If all of the detectors do not respond to Class I, then the same fire is repeated at the class II level. If in Class II, one or more detectors do not respond, then the 
same fire is repeated at the class III level. Following this, or as soon as all detectors have responded in either Class I or Class II, then the procedure is repeated for the next fire type.

A suitability table can then be prepared from the results of the tests of the automatic fire detector. This suitability table would show the response of the detector to each of the test fires in one of the classification grades. If all of the detector specimens tested responded to a class II fire size of one of the test fires, then a mark would be placed in the appropriate column. If none of the detector specimens, or less than all of the specimens, responded to a Class III fire, then no mark would be entered on the line corresponding to this type of fire. Thus, a mark in any column will indicate the smallest fire size to which all detectors responded. No mark would indicate that one or more of the detectors tested did not respond to the largest fire size for a specific fire type. Table 8, taken from reference [2], represents a typical response of an ionization chamber smoke detector. Table 9, from reference [4], represents a typical response of a photoelectric smoke detector. Table 10, from reference [2], gives a typical response for a heat detector while table 11, from reference [4], gives the typical response for a flame detector. 
It should be reasonably obvious that the tabular presentation of the test results for a specific automatic fire detector, as shown on these tables, yields useful information with respect to the suitability or applicability of a given detector for a specific fire risk. For instance, if the most probable type of fire to be expected in an occupancy can be forecast with reasonable accuracy, which is often possible, then the type of detector offering the quickest detection capabilities for that type of fire can be selected from the results on the suitability table.

Another important feature of the test method I am proposing here is that these tests can be performed in just about any test facility without the need for large, expensive testing facilities. Further, the proposed test method will reduce all the many and varied test procedures we now have, depending on the device to be tested, to a series of tests having a large measure of commonality, a very desirable objective, in my opinion.

Much work needs to be done before this proposed test procedure for automatic fire detection devices will be ready for consideration as a U.S. test standard. This is one of the main objectives of the detection program at NBS and I 
hope that others in the U.S. will take an earnest look at this proposed test procedure, also.

It is likely that in time this same test method will be proposed for international adoption through the International Standards Organization (ISO) procedures. The test method seems much superior to anything we have presently in the U.S. As a consequence, it is my opinion that the faster we can move towards adoption of this test method the better we will be for it. 
REFERENCES

[1] Richtlinien für Automatische Brandmeldeanlagen: Anforderungen and Prufomethoden für Punktförmige Rauchand wärmemelder, (Guidelines for Automatic Fire Detection Facilities: Requirements and Testing Methods for Point Smoke and Heat Detectors), Verband der Sachversicherer e.V., Cologne (Nov. 1973).

[2] Test Methods for Point Smoke Detectors, Groupe de Travail Incendie du Comite Europeen des Assurances, Comite Technique Permanent, Paris (April 1974).

[3] Test Methods for Point Heat Detectors, Groupe de Travail Incendie du Comite Europeen des Assurances, Comite Technique Permanent, Paris (Nov. 1973).

[4] Schnell, M., Points of View in Testing Flame Detectors, Nat. Bur. Stand. (U.S.), NBSIR 76-1040 (May 1976). 


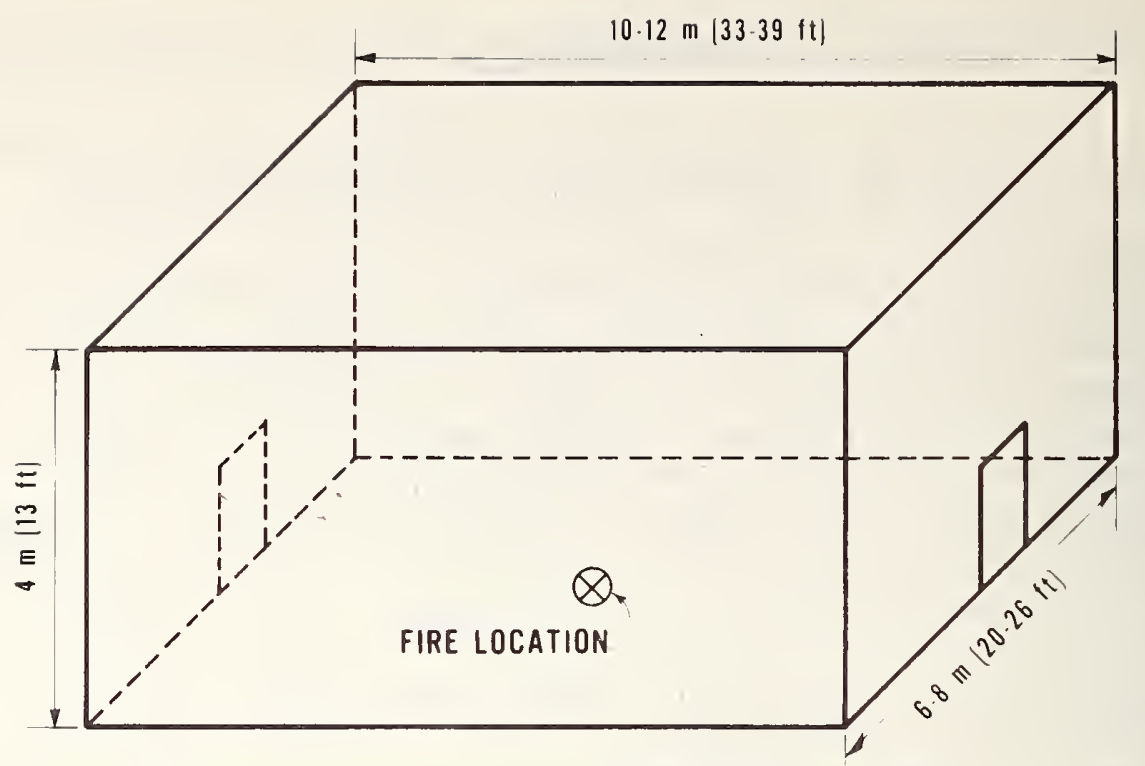

Fig. 1. GEOMETRY OF DETECTOR TEST LABORATORY

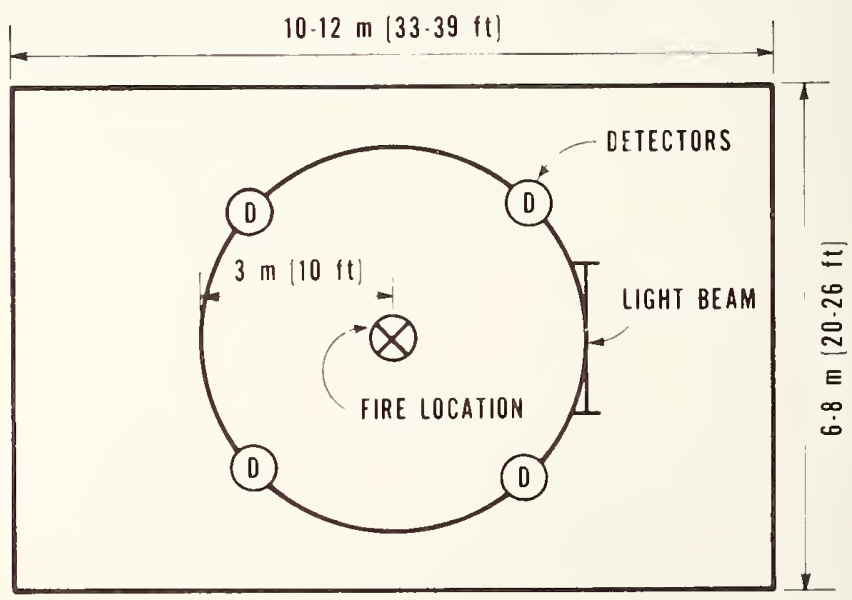

Fig. 2. POSITION OF THE DETECTORS AND MEASURING DEVICES ON CEILING OF DETECTOR TEST LABORATORY 


\section{Table 1. Types of Automatic \\ Fire Detection Devices}

HEAT

- Fixed Temperature

- Rate-of-Rise

- Combination of Above

- Laser Beam

\section{SMOKE}

- Photoelectric

- Ion Chamber

- Extinction Beam.

- Cloud Chamber

- Laser Beam

- Taguchi

- Fuel Cell

RADIATION

- Infrared

- Ultra Violet

- Combination of Above 
Table 2. Proposed Standard Test Fires

Test Fire

Type of Test Fire/Fuel Material

Test Fire No. 1

Flaming Cellulosic - Well-ventilated, Wood Crib

Test Fire No. 2

Smoldering Cellulosic - Wood Strips on a. Hot Plate

Test Fire No. 3

Flaming Plastic - Flexible Polyurethane Mats

Test Fire No. 4

Flammable Liquid with Pronounced Smoke Production - Heating Oil or Kerosene

Test Fire No. 5

Flammable Liquid with Pronounced Heat but Little Smoke - Methyl Alcohol 
Table 3. Test Fire No. 1 - Flaming Cellulosic

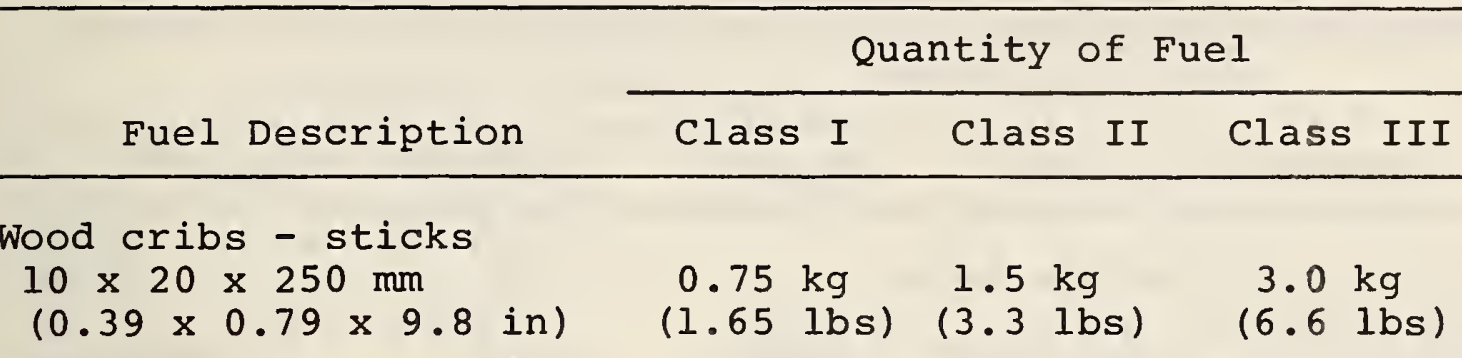

Wood cribs - sticks

Base area of crib - mm $\begin{array}{cccc}250 \times 250 & 250 \times 250 & 250 \times 400 \\ (\text { in }) & (9.8 \times 9.8) & (9.8 \times 9.8) & (9.8 \times 15.7)\end{array}$

Table 4. Test Fire No. 2 - Smoldering Cellulosic

\begin{tabular}{l} 
Quel Description \\
\cline { 2 - 3 } Class I $\quad$ Class II Class III
\end{tabular}

Wood strips on hot plate

Strips, $10 \times 20 \times 50 \mathrm{~mm}$, $(0.39 \times 0.79 \times 2.0$ in). No flame

$\begin{array}{ccc}3 & 6 & 12 \\ \text { Strips } & \text { Strips } & \text { Strips }\end{array}$

Hot plate, $180 \mathrm{~mm}$ in

diameter $(7$ in), 1.3

$\mathrm{kW}$ power, surface

temperature - 400 to

$450^{\circ} \mathrm{C}\left(752\right.$ to $\left.842^{\circ} \mathrm{F}\right)$ 
Table 5. Test Fire No. 3-Flaming Plastic

\begin{tabular}{ll} 
& \multicolumn{3}{c}{ Quantity of Fuel } \\
\cline { 2 - 4 } Fuel Description & Class I Class II Class III
\end{tabular}

Flexible polyurethane mats.

No inhibitors

Density - $20 \mathrm{~kg} / \mathrm{m}^{3}(1.25$

1

$\left.\mathrm{lbs} / \mathrm{ft}^{3}\right)$ Size $-20 \times 400$

Mats

2

3

x $500 \mathrm{~mm}(0.79 \times 15.7 \times$

19.7 in) Mats laid on

aluminum foil with edges

folded up. Ignition by

$5 \mathrm{~g}$ of methyi alcohol.

Table 6. Test Fire No. 4 - Flammable Liquid w/Smoke

Fuel Description $\frac{\text { Quantity of Fuel }}{$\cline { 2 - 3 } \text {$Class I Class II Class III }}$

Heating oil in square, metal trays with $20 \mathrm{~mm}$ $(0.79$ in) sides. Fuel quantities -

$\begin{array}{crr}15 \mathrm{~g} & 25 \mathrm{~g} & 40 \mathrm{~g} \\ (0.53 \mathrm{oz}) & (0.88 \mathrm{oz}) & (1.4 \mathrm{oz}) \\ & & \\ 25 \mathrm{~cm}^{2} & 50 \mathrm{~cm}^{2} & 100 \mathrm{~cm}^{2} \\ \left(3.9 \mathrm{in}^{2}\right) & \left(7.7 \mathrm{in}^{2}\right) & \left(15.5 \mathrm{in}^{2}\right)\end{array}$

Tray areas -

Ignition by hot wire or with $5 \mathrm{~g}$ of gasoline 
Table 7. Test Fire No. 5 - Flammable Liquid w/Heat

\begin{tabular}{|c|c|c|c|c|}
\hline \multirow{2}{*}{ Fuel Description } & \multicolumn{4}{|c|}{ Quantity of Fuel } \\
\hline & Class I & Class II & Class & II I \\
\hline $\begin{array}{l}\text { Methyl alcohol in squa } \\
\text { metal trays w/50 mm } \\
\text { ( } 2 \text { in) sides. Fuel } \\
\text { quantities - }\end{array}$ & $\begin{array}{c}1.2 \mathrm{~kg} \\
\left(2.6^{1 \mathrm{bs}}\right)\end{array}$ & $\begin{array}{l}1.6 \mathrm{~kg} \\
(3.5 \mathrm{lbs})\end{array}$ & $\begin{array}{r}2.0 \\
(4.4\end{array}$ & $\begin{array}{ll}0 & \mathrm{~kg} \\
4 & \mathrm{lbs})\end{array}$ \\
\hline Tray areas - & $\begin{array}{l}1100 \mathrm{~cm}^{2} \\
\left(170 \mathrm{in}^{2}\right)\end{array}$ & $\begin{array}{l}1500 \mathrm{~cm}^{2} \\
\left(232 \mathrm{in}^{2}\right)\end{array}$ & $\begin{array}{l}1900 \\
(294\end{array}$ & $\begin{array}{ll}0 & \mathrm{~cm}^{2} \\
4 & \mathrm{in}^{2}\end{array}$ \\
\hline
\end{tabular}


Table 8. Fire Detector Classification Table Typical Results for: Ionization Smoke Detector

\begin{tabular}{llll}
\hline & Type of Fire & \multicolumn{2}{c}{ Classification } \\
\cline { 2 - 3 } & I & II & III \\
\hline No. 1 - Flaming Cellulosic & $\mathrm{X}$ & \\
\hline No. 2 - Smoldering Cellulosic & & $\mathrm{X}$ \\
\hline No. 3 - Flaming Plastic & & $\mathrm{X}$ \\
\hline No. 4 - Flammable Liquid (Fuel Oil) & & \\
\hline No. 5 - Flammable Liquid (Alcohol) & & \\
\hline
\end{tabular}

From: Reference [2] 
Table 9. Fire Detector Classification - Typical Results for: Photoelectric Smoke Detector

$$
\text { Type of Fire }
$$

Classification

I II III

No. 1 - Flaming Cellulosic

$\mathrm{x}$

No. 2 - Smoldering Cellulosic $\mathrm{x}$

No. 3 - Flaming Plastic

$\mathrm{x}$

No. 4 - Flammable Liquid (Fuel Oil)

$\mathrm{x}$

No. 5 - Flammable Liquid (Alcohol)

From: Reference [4] 
Table 10. Fire Detector Classification - Typical Results for: Heat Detector

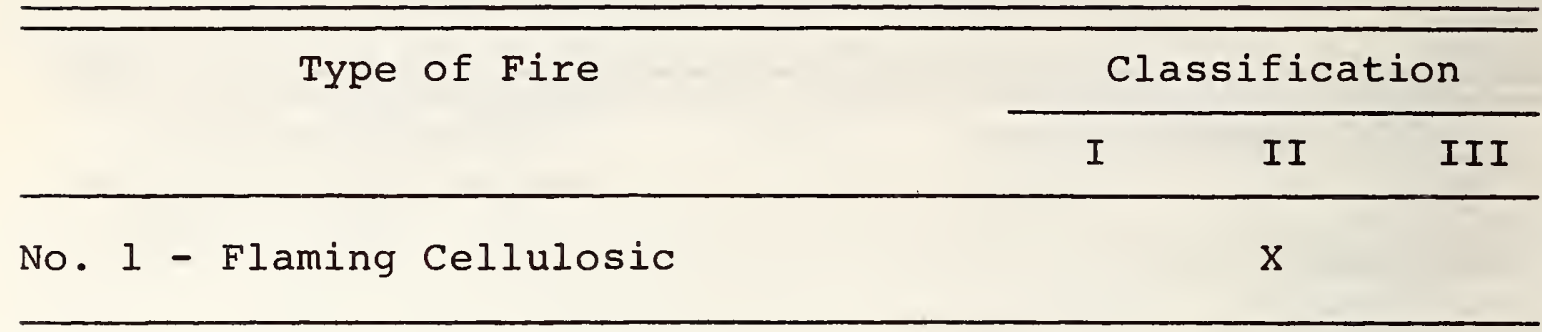

No. 2 - Smoldering Cellulosic

No. 3 - Flaming Plastic

No. 4 - Flammable Liquid (Fuel Oil)

No. 5 - Flammable Liquid (Alcohol) $\mathrm{X}$

From: Reference [3] 
Table 11. Fire Detector Classification - Typical Results for: Infrared Flame Detector

Type of Fire

Classification

I II III

No. 1 - Flaming Cellulosic

No. 2 - Smoldering Cellulosic

No. 3 - Flaming Plastic

$\mathrm{x}$

No. 4 - Flammable Liquid (Fuel Oil)

$\mathrm{x}$

No. 5 - Flammable Liquid (Alcohol)

$\mathrm{x}$

From: Reference [4] 
NBS-114A IREV. 7.73)

\begin{tabular}{|c|c|c|c|}
\hline $\begin{array}{l}\text { U.S. DEPT. OF COMM. } \\
\text { BIBLIOGRAPHIC DATA } \\
\text { SHEET }\end{array}$ & $\begin{array}{l}\text { 1. PUIAIICATION OR RIEPORT NO. } \\
\text { NBSIR 76-1172 }\end{array}$ & $\begin{array}{l}\text { 2. Gov't Accession } \\
\text { No. }\end{array}$ & 3. Recipient's Accession No. \\
\hline \multirow{2}{*}{\multicolumn{3}{|c|}{$\begin{array}{l}\text { 4. TITLE ANI SUBTITIL: } \\
\text { A NEW TEST METHOD FOR AUTOMATIC FIRE DETECTION } \\
\text { DEVICES }\end{array}$}} & $\begin{array}{l}\text { 5. Publication Date } \\
\text { December } 1976\end{array}$ \\
\hline & & & 6. Performing Organization Code \\
\hline \multicolumn{3}{|c|}{$\begin{array}{l}\text { 7. AUTHOR(S) } \\
\text { Richard G. Bright }\end{array}$} & 8. Performing Organ. Report No. \\
\hline \multirow{2}{*}{\multicolumn{3}{|c|}{$\begin{array}{l}\text { 9. PERFORMING ORGANIZATION NAME AND ADDRESS } \\
\text { NATIONAL BUREAU OF STANDARDS } \\
\text { DEPARTMENT OF COMMERCE } \\
\text { WASHINGTON, D.C. } 20234\end{array}$}} & $\begin{array}{l}\text { 10. Project/Task/Work Unit No. } \\
4928677\end{array}$ \\
\hline & & & 11. Contract/Grant No. \\
\hline \multicolumn{4}{|c|}{\begin{tabular}{c|c} 
12. Sponsoring Organization Name and Complete Address (Street, City, State, ZIP) & $\begin{array}{c}\text { 13. Type of Report \& Period } \\
\text { Covered } \\
\text { Final Report }\end{array}$ \\
\cline { 2 - 3 } 9 & Samal Repor
\end{tabular}} \\
\hline & & & 14. Sponsoring Agency Code \\
\hline
\end{tabular}

15. SUPPLEMENTARY NOTES

16. ABSTRACT (A 200-word or less factual summary of most significant information. If document includes a significant bibliography or literature survey, mention it here.)

An analysis of the test methods for automatic fire detection devices in the U.S. reveals the fact that different types and different sizes of fires are used to evaluate different classes of detectors. The result is a lack of comparison test data for each detector class and, as a consequence, intelligent decisions can not be made in the selection of automatic fire detectors for specific fire risks. A new test method is proposed in which all automatic fire detectors, regardless of sensor type, would be subjected to a series of the same test fires. In addition, each test fire series would consist of three different test fire sizes. From the results obtained, it should then be possible to match a detector's characteristics against a specific fire risk resulting in a more intelligent application of automatic fire detectors.

17. KEY WORDS (SIx to twelve entries; alphabetical order; capitalize only the first letter of the first key word unless a proper name; separated by semicolons)

Fire detector; test methods.

18. AVAILABILITY $\quad[\mathrm{X}$ Unlimited

For Official Distribution. Do Not Release to NTIS

Order From Sup. of Doc., U.S. Government Printing Office Washington, D.C. 20402, SD Cat. No.C13

[X] Order From National Technical Information Service (NTIS) Springfield, Virginia 22151

\begin{tabular}{|l|c|}
\hline $\begin{array}{l}\text { 19. SECURITY CLASS } \\
\text { (THIS REPURT) }\end{array}$ & 21. NO. OF PAGES \\
UNCL ASSIFIED & 28 \\
\hline $\begin{array}{l}\text { 20. SECURITY CLASS } \\
\text { (TIIIS PAGE) }\end{array}$ & 22. Price \\
UNCLASSIFIED & $\$ 4.00$ \\
\hline
\end{tabular}


76-1173 CANCELLED 




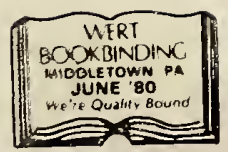


